\title{
Study of aetiopathogenesis of chronic leg ulcers
}

\author{
Authors \\ Parikshita Dalai $^{1}$, Swapnarani Behera ${ }^{2}$, Nikhil Muduli ${ }^{3}$ \\ ${ }^{1}$ Associate Professor, Department of General Surgery, SCB MCH, Cuttack, India \\ ${ }^{2}$ Associate Professor, Department of Skin \& Venereal Diseases, SCB MCH, Cuttack, India \\ ${ }^{3}$ Junior Resident, Department of General Surgery, SCB MCH, Cuttack, India \\ *Corresponding Author \\ Dr Swapnarani Behera
}

\begin{abstract}
Background: An ulcer is a discontinuity of an epithelial surface. There is usually progressive destruction of surface tissue. Chronic ulceration of the lower legs is a relatively common condition amongst adults, one that causes pain and social distress. The prevalence of active leg ulceration has been found to be $0.15 \%$. The common causes are venous disease, arterial disease and neuropathy. The prevalence of leg ulcers has considerable variation geographically and within ethnic group. No adequate literature on prevalence and aetiopathogenesis of chronic leg ulcers in Eastern Indian population is present till date.

Objectives: To study the prevalence and aetiopathogenesis of chronic leg ulcers in Eastern Indian population.

Methods: A prospective study was carried out in Sri Rama Chandra Bhanja medical College, Cuttack in the year 2019. Detailed history and examination findings of 60 patients who had presented with chronic leg ulcers were studied.

Results: The incidence rate of chronic leg ulcers among patients presenting to OPD was 0.14\%. Males in rural area had higher incidence with a peak in middle age group, i.e, 41-50 years. Most common aetiology was found to be leprosy (60\%) followed by venous ulcer (16.6\%) and diabetic ulcer (11.6\%).

Conclusion: Incidence of chronic leg ulcers in Eastern Indian population is comparable to that of other literature available and leprosy is still a common cause of chronic leg ulcers unlike seen in studies from other regions.
\end{abstract}

Keywords: Chronic leg ulcers, Eastern India, aetiopathogenesis.

\section{Introduction}

An ulcer is a discontinuity of an epithelial surface. There is usually progressive destruction of surface tissue. Leg ulcers have become now a great problem in our developing country both physically and socially due to rapid urbanisation and environmental imbalance in a rapidly growing population producing more and more health associated problems. The leg ulcers are common problem of human being and it is a significant cause of morbidity for a person throughout life and most distressing when it is chronic in nature. The chronic leg ulcers condition has perplexed the physician as well as dermatologist till date. The prevalence of leg ulcers has considerable variation geographically and within ethnic group. The prevalence of active leg 


\section{JMSCR Vol||08||Issue||05||Page 543-549||May}

ulceration has been found to be $0.15 \%$ (MJ Callam, CV Ruckleg, DR Harper et al 1985). The cutaneous abnormality characterised by induration, dermatitis, hyperpigmentation, varicosity, oedema and ulceration has been recognised as chronic distressing leg syndrome for centuries. The statistical data regarding the prevalence of leg ulcer varies from place to place depending upon environmental condition. The leg ulcers can be classified as follows:

\section{Venous ulcer (Stasis ulcer, Varicose Ulcer)}

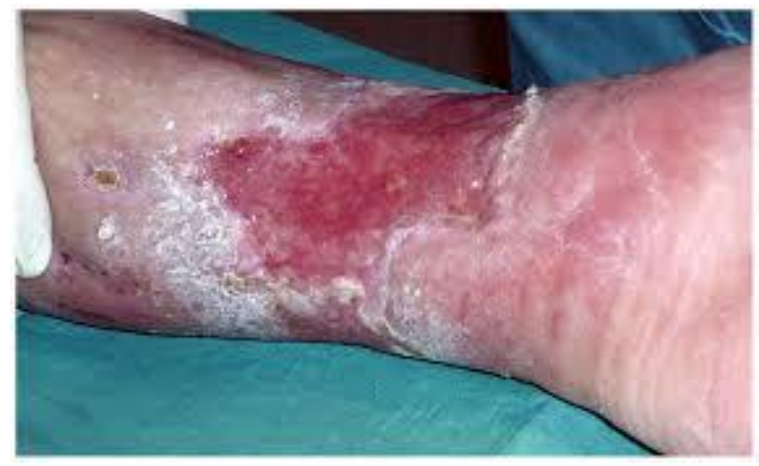

Fig-1

90\% of all leg ulcers result from chronic venous insufficiency. It occurs on the lower medial aspect of leg (fig-1), usually there is proceeding venous stasis, dermatitis with lipodermatosclerosis.

2. Ulcers due to Arterial Insufficiency 5\% of all leg ulcers from arteriosclerosis obliterans.

\section{Neuropathic ulcer}

a. Necrobiosis lipoidica diabeticorum occurs in about $0.3 \%$ of diabetics (fig-2).

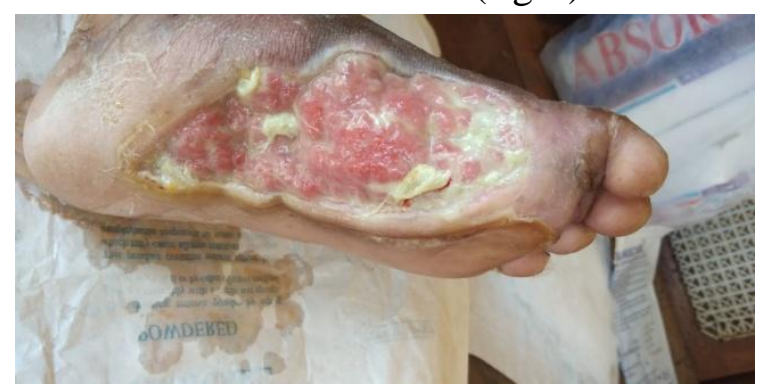

Fig-2

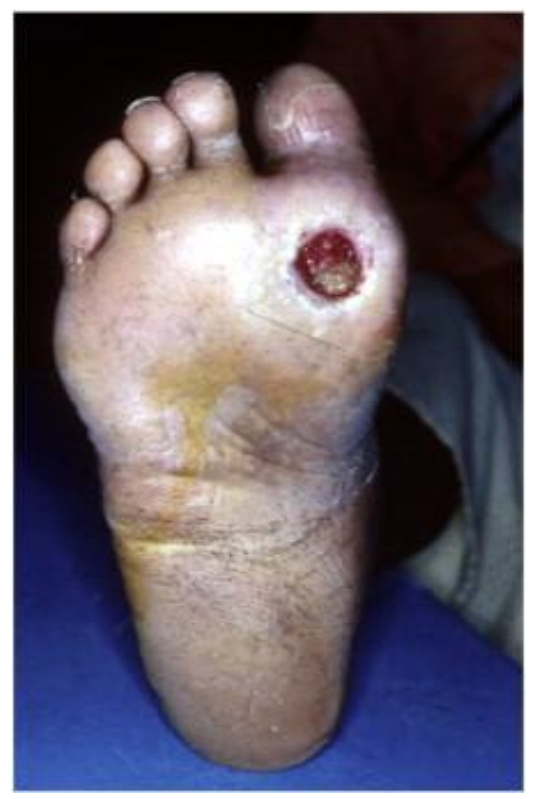

Fig-3

b. Trophic ulcer (fig-3) from Hansen's disease $10-20 \%$ of all leprosy patients suffer from trophic ulcer.

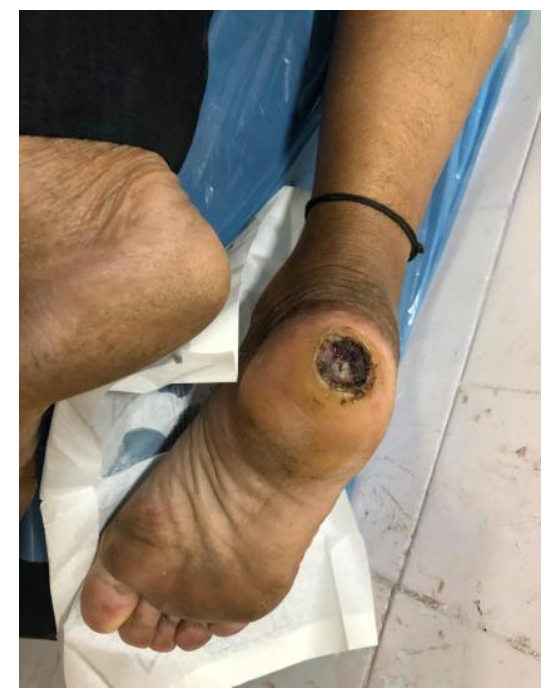

Fig-4

c. Ulcers from spinal cord lesion like Tabes Dorsalis (fig-4), syringomyelia, peripheral neuropathy.

\section{Hypertensive ulcer}

\section{Infective ulcer}

a) Bacterial- Lupus vulgaris, Mycobacterial ulcer (Buruli ulcer)

b) Fungal-Blastomycosis, coccidiodomycosis, histoplasmosis

c) Parasite-Dracunculosis, Schistosomiasis.

d) Unknown etiology - Pyoderma gangrenosum 


\section{Haematopoietic ulcer}

Sickle cell anaemia,

Thalassemia (Cooley's anaemia)

Polycythemia vera

Thrombocytopenic purpura

Macroglobulinemia.

Cryoglobulinemia.

\section{Neoplastic ulcer}

Basal cell carcinoma.

Squamous cell carcinoma

Malignant Melanoma

Sarcoma

Kaposi's sarcoma

Malignant Lymphoma

8. Other-Collagen vascular diseases like

SLE

Felty's syndrome

Rheumatoid arthritis

Scleroderma

Porphyria Cutanea tarda

\section{Nonspecific Ulcer}

Burns

Decubitus ulcer

Factitial ulcer

This study is aimed to know various aetiological factors causing ulcers in the leg and to detect the various pathological processes involved in ulcer formation. Chronic ulceration of the leg, often causing considerable disability, is a common problem with significant economic consequences for the individual and society. The diagnosis of leg ulcer is totally inadequate and must always be qualified by a statement of the cause, backed by full evidence for this diagnosis. This requires an understanding of the range of leg ulcers that occur and the disease processes underlying them. So it is important to identify accurately the underlying cause in each case so that treatment may be correctly based on this. The dreaded prognosis of chronic leg ulceration is the loss of limb and permanent deformity for which patient as well as doctor both should be very careful. There is no available statistical data about chronic leg ulcers in state of Odisha. This study has been taken to throw some light on this subject especially about its prevalence and aetiopathogenesis so that it will be easier for treatment purpose as well as for preventing aspects also.

\section{Materials \& Methods}

The present study was carried out in 60 patients with chronic leg ulcers attending the O.P.D. \& indoor of Dept. of Skin \& V.D. of S.C.B. Medical College Hospital, Cuttack from the month of January 2018 to January 2019. Detailed history was taken in every case. Those cases were examined and findings were recorded in the proforma. Presenting features were recorded in chronological order with special reference to their sequence and time interval. In history of present illness, mode of onset of ulcer with duration and progress of disease, presence of anaesthesia were noted in details, History of past illness includes association of any previous chronic diseases, neurological deficiency or history of trauma. Occupation of patients was taken into account. Family history includes any other family member of either side with history of similar disease. Personal history shows socio-economic status with habits and addictions.

General Examination included body built and nutrition status, pallor, icterus, oedema, lymph node status, pulse rate, blood pressure \& respiratory rate.

Local examination consists of inspection and palpation of ulcer site. Inspection of ulcer site included situation, extent, number, size, shape, edge, floor, colour and discharge from ulcer. Palpation included site, extent, margin, base and surface confirmed with associated rise of local temperature and tenderness. Lymph nodes palpated and recorded their number, site, consistency, mobility, fixity and ulceration.

Systemic examination includes examination of cardiorespiratory system, nervous system, skeletal system and abdomen.

In special cases, arteriography was done to rule out vascular insufficiency and abnormality. 


\section{Results and Discussion}

The present study was carried out in the Department of Skin \& VD and Leprosy of S.C.B. Medical College Hospital, Cuttack. Out of a total no. of 42,570 patients attending the OPD during the period of two years from Jan-18 to Jan.-19, 60 patients having chronic leg ulcers were selected.

\section{Table-I}

\begin{tabular}{|c|c|c|}
\hline Sl. No. & Variable & Total $(n=60)(\%)$ \\
\hline 1 & $\begin{array}{l}\text { Age groups } \\
21-30 \\
31-40 \\
41-50 \\
51-60 \\
61-70\end{array}$ & $\begin{array}{c}3(5) \\
17(28.3) \\
23(38.3) \\
10(16.6) \\
7(11.6)\end{array}$ \\
\hline 2 & $\begin{array}{l}\text { Aetiology } \\
\text { Leprosy } \\
\text { Venous ulcer } \\
\text { Diabetic ulcer } \\
\text { Spinal cord disease } \\
\text { Pyoderma gangrenosum } \\
\text { Arteriosclerosis } \\
\text { Non-specific ulcers } \\
\end{array}$ & $\begin{array}{c}36(60) \\
10(16.6) \\
7(11.6) \\
2(3.3) \\
1(1.6) \\
1(1.6) \\
3(6) \\
\end{array}$ \\
\hline 3 & $\begin{array}{l}\text { Duration of ulcer } \\
0-6 \\
7-12 \\
13-18 \\
19-24\end{array}$ & $\begin{array}{l}13(21.7) \\
21(35) \\
16(26.6) \\
10(16.6)\end{array}$ \\
\hline 4 & $\begin{array}{l}\text { Habitat } \\
\text { Rural } \\
\text { Urban }\end{array}$ & $\begin{array}{l}42(70) \\
18(30)\end{array}$ \\
\hline 5 & $\begin{array}{l}\text { Socioeconomic status } \\
\text { Poor } \\
\text { Middle } \\
\text { Well to do }\end{array}$ & $\begin{array}{l}40(66.6) \\
15(25) \\
5(8.3)\end{array}$ \\
\hline 6 & $\begin{array}{l}\text { Addiction } \\
\text { Chewing paan } \\
\text { Smoking } \\
\text { Alcohol } \\
\text { No addiction }\end{array}$ & $\begin{array}{c}15(25) \\
14(23.3) \\
8(13.3) \\
23(38.3)\end{array}$ \\
\hline
\end{tabular}

The incidence rate is $0.14 \%$ as observed in above table-I among the patients attending in skin \& VD OPD within the study period.

From the above table it was seen that maximum number of patients $(38.3 \%)$ were in the age group of 41-50 yrs. Least number of patients were seen between the age group of $21-30 \mathrm{yrs}(5 \%)$. It was also observed that the maximum number of chronic leg ulcer cases was seen in leprosy $(60 \%)$, next due to stasis/venous ulcers (16.6\%) and in diabetes $(11.6 \%)$. Data also signifies that maximum number of patients $(35 \%)$ presented with chronic leg ulcers with 7-12 months of duration. Least number of patients presented during 19-24 months. 42 patients (70\%) were from rural areas where as 18 cases (30\%) were from urban area. Highest number of 40 cases $(66.6 \%)$ belonged to poor socioeconomic status. 15 cases $(25 \%)$ from middle class and rest 5 patients $(8.3 \%)$ belonged to well to do family. It was observed that 23 cases $(38.3 \%)$ were not addicted to betel nut, smoking, alcohol, etc. 15 cases were addicted to paan (25\%), 14 cases $(23.3 \%)$ to smoking and 8 cases (13.3\%) were addicted to alcohol.

\section{Conclusion}

This is a study conducted within a period of 2 years from January - 18 to January - 19 to evaluate the aetiopathogenesis of chronic leg ulcers. There were 60 patients involved in this study. Out of which maximum patients were from leprosy $(60 \%)$. Rest of the ulcers were presented in chronological order as venous ulcer (16.6\%), diabetic ulcers (11.6\%), ulcers due to spinal cord disease $(3.3 \%)$, ulcer from pyoderma gangrenosum and arterial insufficiency $(1.6 \%)$ and non specific ulcers (5\%). The incidence of chronic leg ulcers has increased as the age advances and males are more affected due to their outdoor activity than females. Regarding habit, habitat and socioeconomic status, low socioeconomic group with rural origin, affected more than the urban people with good economical condition which has got no specific relation to addiction /habituation with exception for vascular diseases like arteriosclerosis obliterans and diabetes mellitus. Besides routine investigations like haemogram, FBS, urea, creatinine, VDRL a few special investigations like biopsy from ulcer margin for histopathological study, arteriography was done for selected vascular diseases causing ulcer. Nonspecific changes were seen from histopathological study in ulcers like trophic ulcer and other infective ulcers except neoplastic ulcer like squamous cell carcinoma. Leg ulcers are common problem and lead to suffering, disability, frequent hospitalisation and a great expense to both the patient and community. The clinical course of chronic leg ulcers is episode of recurrence followed 
by healing. Besides few non-specific and bacterial ulcer all other chronic leg ulcers are very problematic condition for a patient throughout his life. So immediate care should be taken to assess the aetiopathogenesis of ulcers for better treatment care and to avoid loss of a limb.

\section{Conflicts of Interest: Nil}

\section{References}

1. B. Kahle, H. J. Hermanns, and G. Gallenkemper, "Evidence based treatment of chronic leg ulcers," Deutsches Arzteblatt " International, vol. 108, no. 14, pp. 231-237, 2011.

2. W. B. van Gent, E. D. Wilschut, and C. Wittens, "Management of venous ulcer disease," The British Medical Journal, vol. 341, no. 7782, pp. 1092-1096, 2010.

3. R. V. Gonzalez-Consuegra and J. Verd ' u, "Quality of life in ' people with venous leg ulcers: an integrative review," Journal of Advanced Nursing, vol. 67, no. 5, pp. 926944, 2011.

4. C. S. Sasanka, "Venous ulcers of the lower limb: where do we stand?" Indian Journal of Plastic Surgery, vol. 45, no. 2, pp. 266-274, 2012.

5. O. Amir, A. Liu, and A. L. S. Chang, "Stratification of highest risk patients with chronic skin ulcers in a Stanford retrospective cohort includes diabetes, need for systemic antibiotics, and albumin levels," Ulcers, vol. 2012, Article ID 767861, 7 pages, 2012.

6. R. Rayner, K. Carville, J. Keaton, J. Prentice, and X. N. Santamaria, "Leg ulcers: atypical presentations and associated comorbidities," Wound Practice and Research, vol. 17, no. 4, pp. 168-185, 2009.

7. C. F. Cheng, D. Sahu, F. Tsen et al., "A fragment of secreted Hsp90 $\alpha$ carries properties that enable it to accelerate effectively both acute and diabetic wound healing in mice," The Journal of Clinical
Investigation, vol. 121 , no. 11, pp. 43484361, 2011.

8. G. A. Rahman, I. A. Adigun, and A. Fadeyi, "Epidemiology, etiology, and treatment of chronic leg ulcer: experience with sixty patients," Annals of African Medicine, vol. 9, no. 1, pp. 1- 4, 2010.

9. J. R. Mekkes, M. A. M. Loots, A. C. van der Wal, and J. D. Bos, "Causes, investigation and treatment of leg ulceration," The British Journal of Dermatology, vol. 148, no. 3, pp. 388-401, 2003.

10. J. F. O'Brien, P. A. Grace, I. J. Perry, and P. E. Burke, "Prevalence and aetiology of leg ulcers in Ireland," Irish Journal of Medical Science, vol. 169, no. 2, pp. 110-112, 2000.

11. E. Faria, L. Blanes, B. Hochman, M. M. Filho, and L. Ferreira, "Health-related quality of life, self-esteem, and functional status of patients with Leg ulcers," Wounds, vol. 23, no. 1, pp. 4-10, 2011.

12. C. K. Sen, G. M. Gordillo, S. Roy et al., "Human skin wounds: a major and snowballing threat to public health and the economy," Wound Repair and Regeneration, vol. 17, no. 6, pp. 763-771, 2009.

13. S. R. Baker and M. C. Stacey, "Epidemiology of chronic leg ulcers in Australia," Australian and New Zealand Journal of Surgery, vol. 64, no. 4, pp. 258261, 1994.

14. A. Korber, J. Klode, S. Al-Benna et al., "Etiology of chronic leg " ulcers in 31, 619 patients in Germany analyzed by an expert survey University Clinic," Journal der Deutschen Dermatologischen Gesellschaft, vol. 9, no. 2, pp. 116-121, 2011.

15. V. K. Shukla, M. A. Ansari, and S. K. Gupta, "Wound healing research: a perspective from India," International Journal of Lower Extremity Wounds, vol. 4, no. 1, pp. 7-8, 2005.

16. X. Fu, Z. Sheng, G. W. Cherry, and Q. Li, "Epidemiological study of chronic dermal 
ulcers in China," Wound Repair and Regeneration, vol. 6, no. 1, pp. 21-27, 1998.

17. X. Fu, "Skin ulcers in lower extremities: the epidemiology and management in China," International Journal of Lower Extremity Wounds, vol. 4, no. 1, pp. 4-6, 2005.

18. A. Jull, N. Walker, V. Parag, P. Molan, and A. Rodgers, "Venous ulcer management in New Zealand: usual care versus guideline recommendations," New Zealand Medical Journal, vol. 122, no. 1295, pp. 9-18, 2009.

19. G. Casey, "Causes and management of leg and foot ulcers," Nursing Standard, vol. 18, no. 45, pp. 57-58, 2004.

20. F. Gottrup and T. Karlsmark, "Leg ulcers: uncommon presentations," Clinics in Dermatology, vol. 23, no. 6, pp. 601-611, 2005.

21. P. K. Sarkar and S. Ballantyne, "Management of leg ulcers," Postgraduate Medical Journal, vol. 76, no. 901, pp. 674682, 2000.

22. M. C. Moloney and P. Grace, "Understanding the underlying causes of chronic leg ulceration," Journal of wound care, vol. 13, no. 6, pp. 215-218, 2004.

23. N. J. M. London and R. Donnelly, "ABC of arterial and venous disease. Ulcerated lower limb," The British Medical Journal, vol. 320, no. 7249, pp. 1589-1591, 2000.

24. A. Adeyi, S. Muzerengi, and I. Gupta, "Leg ulcers in older people: a review of management," The British Journal of Medical Practitioners, vol. 2, no. 3, pp. 2128.

25. A. Aydin, S. Shenbagamurthi, and H. Brem, "Lower extremity ulcers: venous, arterial, or diabetic?" Emergency Medicine, vol. 41, no. 8, pp. 18-24, 2009.

26. L. Collins and S. Seraj, "Diagnosis and treatment of venous ulcers," The American Family Physician, vol. 81, no. 8, pp. 989996, 2010.

27. M. H. Meissner, G. Moneta, K. Burnand et al., "The haemodynamics and diagnosis of venous disease," Journal of Vascular Surgery, vol. 46, no. 6, supplement, pp. S4S24, 2007.

28. J. E. Grey, K. G. Harding, and S. Enoch, "Venous and arterial leg ulcers," The British Medical Journal, vol. 332, no. 7537, pp. 347-350, 2006.

29. H. Newton, "Leg ulcers: differences between venous and arterial," Wounds Essentials, vol. 6, no. 1, pp. 20-28, 2011.

30. G. Irving and S. Hargreaves, "Venous and arterial leg ulceration," InnovAiT, vol. 2, pp. 415-422, 2009.

31. C. Moffatt, "Leg ulcers," in Vascular Disease, S. Murray, Ed., pp. 200-237, Whurr Publishers, London, UK, 2001.

32. S. P. Pendse, "Understanding diabetic foot," International Journal of Diabetes in Developing Countries, vol. 28, no. 5, pp. 519- 526, 2010.

33. W. Clayton and T. A. Elasy, "A review of the pathophysiology, classification, and treatment of foot ulcers in diabetic patients," Clinical Diabetes, vol. 27, no. 2, pp. 52-58, 2009.

34. A. S. K. Ghauri and I. K. Nyamekye, "Leg ulceration: the importance of treating the underlying pathophysiology," Phlebology, vol. 25, supplement 1, pp. 42-51, 2010.

35. S. Dean, "Leg ulcers and management," Australian Family Physicisian, vol. 35, no. 7, pp. 480-485, 2006.

36. C. Burrows, "Leg ulcers," Wound Care Canada, vol. 8, no. 2, pp. 16-18, 2008.

37. A. R. Siddiqui and J. M. Bernstein, "Chronic wound infection: facts and controversies," Clinics in Dermatology, vol. 28, no. 5, pp. 519-526, 2010.

38. A. Han, J. M. Zenilman, J. H. Melendez et al., "The importance of a multi-faceted approach to characterizing the microbial flora of chronic wounds," Wound Repair Regeneration, vol. 19, no. 5, pp. 532-541, 2011. 
39. S. V. Agale, D. R. Kulkarni, A. G. Valand, R. R. Zode, and S. Grover, "Marjolin's ulcer-a diagnostic dilemma," Journal of Association of Physicians of India, vol. 57, no. 8, pp. 593-594, 2009.

40. J. Panuncialman, S. Hammerman, P. Carson, and V. Falanga, "Wound edge biopsy sites in chronic wounds heal rapidly and do not result in delayed overall healing of the wounds," Wound Repair and Regeneration, vol. 18, no. 1, pp. 21-25, 2010.

41. A. V. Singh, L. Subhashree, P. Milani, D. Gemmati, and P. Zamboni, "Interplay of iron metallobiology, metalloproteinases, and FXIII, and role of their gene variants in venous leg ulcer," International Journal of Lower Extremity Wounds, vol. 9, no. 4, pp. 166-179, 2010.

42. P. Vowden, "Arterial disease: medical and future perspectives," in Proceedings of the WUWHS Congress, 2008.

43. J. Banerjee, Y. C. Chan, and C. K. Sen, "Micro RNAs in skin and wound healing," Physiological Genomics, vol. 43, no. 10, pp. 543- 556, 2011.

44. M. R. Schneider, "Micro RNAs as novel players in skin development, homeostasis and disease," The British Journal of Dermatology, vol. 166, no. 1, pp. 22-28, 2012.

45. A. D. Widgerow, "Chronic wounds - is cellular "reception" at fault? Examining integrins and intracellular signalling," International Wound Journal, vol. 10, no. 2, pp. 185-192, 2013.

46. R. S. Kirsner, W. A. Marston, R. J. Snyder, T. D. Lee, and D. I. Cargill, "Spray-applied cell therapy with human allogeneic fibroblasts and keratinocytes for the treatment of chronic venous leg ulcers: a phase 2, multicentre, double-blind, randomized, placebo controlled trial,"The Lancet, vol. 380, no. 9846, pp. 977-985, 2012.
47. V. W. Wong, B. Levi, J. Rajadas, M. T. Longaker, and G. C. Gurtner, "Stem cell niches for skin regeneration," International Journal of Biomaterial, vol. 2012, Article ID 926059, 8 pages, 2012.

48. M. A. C. Frade, J. C. Netto, F. G. Gomes, E. L. Mazzucato, and T. A. M. de Andrade, "Natual membrane dressing and hypersensitivity," Anais Brasileiros de Dermatologia, vol. 86, no. 5, pp. 885-891, 2011.

49. M. A. C. Frade, R. V. C. de Assis, J. C. Netto, T. A. M. de Andrade, and N. T. Foss, "The vegetal biomembrane in the healing of chronic venous ulcers," Anais Brasileiros de Dermatologia, vol. 87, no. 1, pp. 45-51, 2012. 